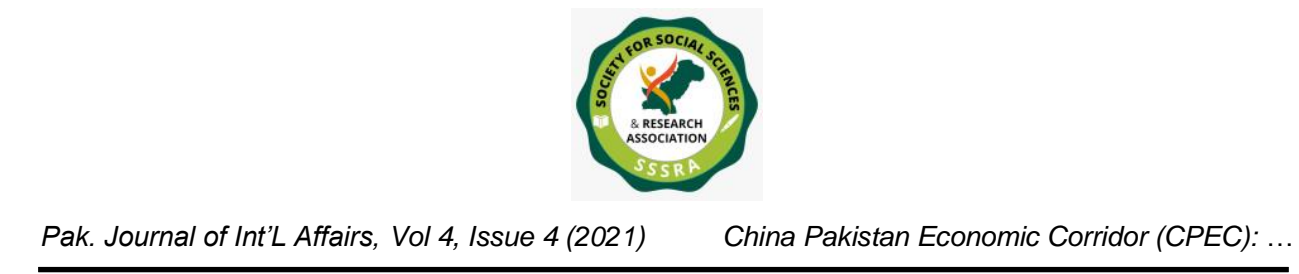

\title{
CHINA PAKISTAN ECONOMIC CORRIDOR (CPEC): OPPORTUNITIES AND THREATS AT DOMESTIC AND REGIONAL CIRCLES
}

\author{
Nasir Abbas \\ PhD research Scholar in Pakistan Studies \\ Baha-ul-din Zakrya University \\ Multan - Pakistan \\ davidbaloch82@gmail.com \\ Prof. Dr. Muhammad Ishaque Fani \\ Department of Pakistan Studies \\ Baha-ul-din Zakrya University \\ Multan - Pakistan \\ fanibzu@gmail.com
}

\begin{abstract}
It is believed that China Pakistan Economic Corridor (CPEC) would bring peace and prosperity in domestic as well as regional circles of Pakistan. This project carries many different perspectives including domestic employments and regional connectivity. Although a lot of work has been done on the project of CPEC already but in this article, an attempt has been made to understand the importance of the project CPEC in the domestic domain of employment and regional connectivity concerns with its opportunities and threats to the project. The main contribution to support this article is the review of literature focusing China Pakistan Economic Corridor (CPEC) a blessing for Pakistan and addressing political, economic and strategic challenges and threats to the project. The paper concludes with possible managerial suggestions to eradicate the threats to the project by stakeholders' participation in the China Pakistan Economic Corridor (CPEC).
\end{abstract}

Key Words: CPEC, One Belt One Road, Domestic and Regional developments, Gwadar Port, Energy sector, Infrastructure development, Employment, Threats

\section{Introduction}

Chinese Premier Li Keqiang made his official visit to Pakistan in 2013 and showed his interest to the deep sea port of Gwadar in southern Pakistan. The two sides agreed to shape the plan and the link became known as CPEC (China Pakistan Economic Corridor) and 


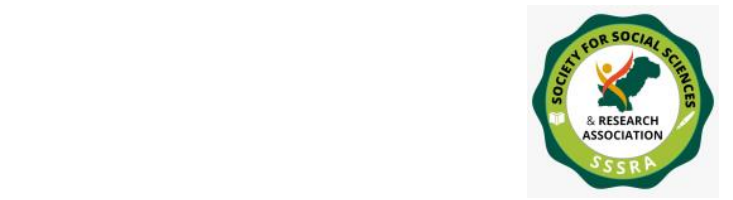

China Pakistan Economic Corridor (CPEC): ...

includes various projects of electricity, oil and gas pipelines, roads, railways, special economic zones, fiber optic networks, Gwadar port, Gwadar city (McCartney, 2018). CPEC is part of huge infrastructure project that will involve almost sixty countries known as the One Belt One Road (OBOR). OBOR has become the significant part of the Chinese foreign policy under president Xi Jiping (McCartney, 2018).

China Pakistan Economic Corridor (CPEC) is an important development of Pakistan China friendship which connects Kashgar a western region of China with Pakistan's Gwadar port situated in the southwest region of Pakistan via Khunjrab Pass across the Karakoram Range (Khan, 2017). The project of CPEC covers a long distance of about 3000 Kilometres in connecting two sides. Through this vital project China has planned to invest an enormous amount of almost US $\$ 46$ billion to develop various sectors of Pakistan within a time frame of about 10-15 years (Ali, 2016). According to the terms and conditions of the CPEC project, China will invest about US\$34 billion in the energy sector of Pakistan in producing 17,000 megawatts electricity to enhance the generation capacity of national grid of Pakistan (Khan, 2017). The remaining amount of US\$12 billion will be spend in other sectors like infrastructure development, transport and communication development and upgrading the roads and railway system of Pakistan (Irshad, 2015).

The planned investment in various sectors is further divided into various branches for instance energy sector includes coal, hydroelectricity, wind, solar and liquefied natural gas etc, similarly, transport and communications consists of roads, railway track, aviation, oil, optical fiber line and gas pipeline etc. The completion period of all the projects in various sectors is 15 years and it will be completed in four phases: in the first phase, early harvest projects will be focused to be completed till 2018, in the second phase, short term projects will be tried to be completed till 2020, in the third phase, medium term projects will be completed till 2025 while in the fourth phase, long term projects will be given priority to be completed till 2030 (Ali, 2016).

The distribution of the amount to be invested on the project CPEC is explained in the table given below: 


\begin{tabular}{|l|l|}
\hline \multicolumn{2}{|c|}{ Financial Breakdown of CPEC Project } \\
\hline Project Detail & Estimated Cost US\$ Billion \\
\hline Energy Sector & 33.792 \\
\hline Transport Infrastructure & 09.790 \\
\hline Gwadar Port \& Gwadar City & 00.792 \\
\hline Mass Transit Lahore & 01.600 \\
\hline Fiber Optic Project & 00.044 \\
\hline Total Cost & 46.018 \\
\hline
\end{tabular}

SOURCE: Table iii, Financial Breakdown of CPEC Project, Naval Post-Graduate College, California.

The energy projects are further divided into two categories, first energy priority projects second energy actively promoted projects. The energy actively promoted projects are to be recommended by the provinces of Pakistan (Ali, 2018). The amount allocated for energy priority project is US $\$ 21.5$ billion to generate 10,400 megawatts of electricity while amount allocated for energy actively promoted project is US\$12.9 billion to generate 6,645 megawatts of electricity which will eventually enhance the capacity of national grid to double as compared to the previous production (Energy, 2019).

Other important development under CPEC project is the construction of infrastructure including roads and railway lines. Whereas the railway lines are concerned, it is expected that 1,200 kilometers new track will be laid while already existing track of about 3,100 kilometers will be upgraded throughout the country (Markey, \& West, 2016). There are three major routes of CPEC project: Western, Eastern and Central route (Hussain, 2017). The Western route leads its way from Balochistan and Khyber Pakhtunkhwa via Turbat, Panjgur, Qalat, Quetta, Zhob, Dera Ismael Khan and then to Havilian (Abid, \& Ashfaq, 2015). There is a provision for the western route to link it with the neighbouring countries of Afghanistan and Iran through Chaman and Taftan respectively.

The importance of the eastern route is this that it runs through Sindh and Punjab via Karachi, Hyderabad, Sukkhar, Rahim Yar Khan, Multan and the to the Havilian (Abid, \& 


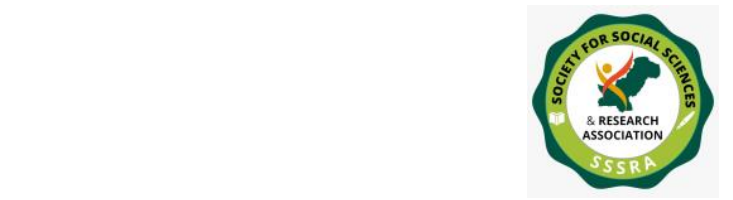

Pak. Journal of Int'L Affairs, Vol 4, Issue 4 (2021)

China Pakistan Economic Corridor (CPEC): ...

Ashfaq, 2015). The Central route is more significant as it links Gwadar to Havilian while passing through the various cities of Balochistan, Sindh and Punjab provinces including Khuzdar, Sukkhar, D.G Khan, Mianwali and Taxila (Abid, \& Ashfaq, 2015). A passage from Taxila can connect central route to Jalalabad of Afghanistan via Peshawar and Torkham. The northern route's another significance is this that it connects Pakistan to China's Kashghar via Havilian through Karakoram Highway (Hussain, Yuan, \& Ali, 2016). The western route is considered more dangerous route because it passes through the undeveloped areas of Balochistan and Khyber Pakhtunkhwa. These areas are considered a security risk for the CPEC project. The eastern route as compared to the other two routes is more peaceful for it passes through the developed areas of Pakistan (Hussain, 2017).

Under the CPEC project there will be almost forty sites from Khunjrab to Gwadar named as Special Economic Zone (SEZ) AND Industrial Parks along with the CPEC routes. In order to establish these Special Economic Zones the Pakistan Government is in consultation with the provincial governments as well as with other stakeholders (Markey, \& West, 2016).

Another domestic development under CPEC project is to promote the railway system of Pakistan. The upgrading and the reconstruction of many tracks is included in the CPEC project i.e. ML1 track of 1736 kilometers from Karachi to Peshawar and the Rail Based Mass Transit System in Provincial Headquarters is also the part of the project CPEC. Few New Railway Tracks has to be constructed in the various regions of the country under the CPEC project. Feasibility studies and the financial arrangements on these projects are yet to be finalized (Khan, 2017).

The most significant development under the CPEC project is the construction of Gwadar port and Gwadar city. The Gwadar port is the heart of whole project, the completion of the Gwadar port would enable the whole project an energy corridor (Khan, Ahmad, \& Xing, 2018). An estimated amount to be invested on Gwadar port is US\$793 million which would be spent on the construction of Gwadar Port, Gwadar City, a new international airport, a hospital and a free economic Zone. For its significance, a wide range of technical workers has been engaged to complete the port within the given time framework (Ali, 2016).

In order to complete the CPEC project within the given timeframe is an important task for both sides. The two sides have agreed to establish a Joint Cooperation Committee at ministerial level for smooth facilitation and implementation of the project. There will be five working groups under this committee, they will look into the matters of energy, transport, Gwadar port, industrial parks and planning. The committee will be co-chaired by 


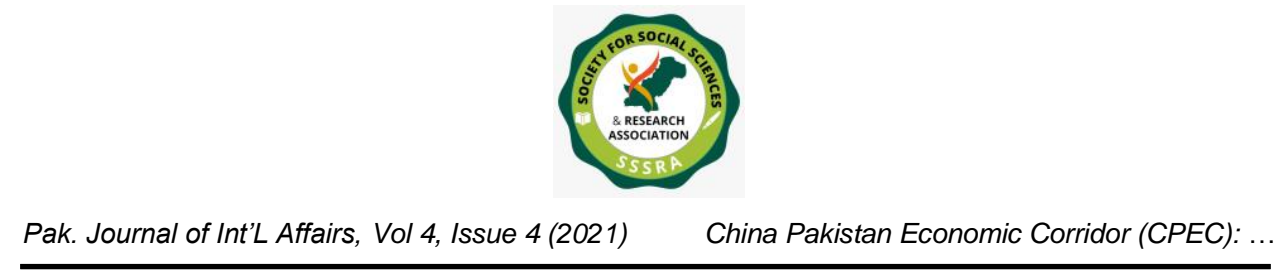

the Minister for Planning and Development of Pakistan and the vice Chairman of NDRC. All tasks and projects will be discussed in the relevant groups first and then will be sent to the committee for its final approval (Ministry of Planning Development and Reforms, 2021).

The important factor for the completion of the CPEC project was the financial assistance, for this purpose China established The Silk Road Fund Co. Ltd. in December 2014. This consortium of important Chinese Banks, such as the China Development Bank and China Exim Bank is providing the finances under the overall management of the aforementioned company. China Export and Credit Insurance Corporation will insure these loans against non-payment risks, while the state will guarantee the security of the loans (Siddique, 2015).

\section{Opportunities}

The CPEC project indicates a new kind of Sino-Pakistan cooperation having the potential to further strengthen their political, strategic and economic relations through trade and development. The CPEC project is not only strategically significant for Pakistan and China but also seems to create regional stability in South Asia (Hussain 2017). Opportunities of the project are far wide as compare to the threats. The gains of the CPEC project are not associated with Pakistan and China but rest of the regional countries seems to be taking advantage of it. In the following paragraphs opportunities of the project are discussed separately:

\section{Opportunities for China}

China Pakistan Economic Corridor is equally important for China and Pakistan. In the following lines this research paper will focus the importance of the project for China. Xinjiang is biggest province of China which covers an area of about one-sixth of China or twice that of Pakistan. Interestingly about 90 percent of the area of this province is uninhabitable while its population is under 25 million and a GDP about half of Pakistan. It shares a 5,000 kilometers land border with eight countries (including Kazakhstan, Kyrgyzstan and Tajikistan - all potential partner through CPEC) (Khan, \& Khan, 2019).

For China, amongst the other gains, CPEC would generate a far more cost - effective and secure transit corridor between Xinjiang, Middle East and Africa than at present. In order to make this transit an economically good for China and its border sharing countries a broad vision, extroverted leadership and four more things are required: 


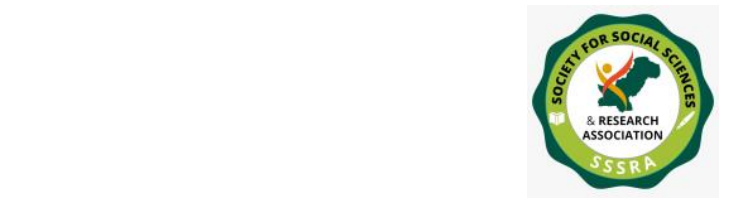

Pak. Journal of Int'L Affairs, Vol 4, Issue 4 (2021)

China Pakistan Economic Corridor (CPEC): ...

1. Existence of cities, areas, and regions with genuine economic potential

2. Innovative research to find out business opportunities and infrastructure needs.

3. Attractive plans, policies and those regulations which could bring genuine investment in international clusters.

4. A serious and continued commitment is essential from the government sectors, private investors and other stakeholders.

China Pakistan Economic Corridor can play a vital role in maximizing economic ties between China, Russia and Central Asian States as Xinjiang's economy basis on agriculture (cotton), livestock (sheep farming and wool production) and mining (oil, natural gas and coal). Despite of all this, in the recent years manufacturing and services have become significant for Xinjiang (China). Xinjiang's exports consisting of textile goods, garments, shoes and electromechanical products which cover an estimated amount of $\$ 18$ billion is made with Russia and Central Asian States while its imports are of worth $\$ 2$ billion consisting of agricultural products, ore, crude oil and medical instruments which are taken from USA, Russia and Central Asian States (Khan, \& Khan, 2019).

Xinjiang is the only province of China sharing its boundary with Central Asian States. A boundary of almost 1000 miles is shared with Kazakhstan, about 700 miles with Kyrgyzstan and approximately 280 miles with Tajikistan (Zhao). Furthermore, Xinjiang (China) is narrowly connected with Central Asian States through ancient traditions, religious bindings and cultural ties.

The project of CPEC will make an easy access of Russia and other Central Asian States towards other parts of China as well as towards the rest of the world at a lower cost and less time margin through $\mathrm{CPEC}$ route transit.

Gwadar port seems to be very effective for China in providing it an easy and cost effective access to the Indian Ocean and further to the Middle East and Africa. The existing maritime distance of $12,000 \mathrm{~km}$ will be reduced to 3,000 km between China and Persian Gulf countries under the shade of CPEC (Ali, 2016). CPEC will provide China an opportunity to import oil from the Middle East and Africa in ten days time as opposed to previous 45 days shipping time (Hussain, Yuan, \& Ali, 2016). The new route is being expected to reduce the transportation cost of oil and other items to one-third as compared to the early charges. By using CPEC route China can save an amount of almost US\$2 billion annually. CPEC offers an economical and secure route from Gwadar port to the Indian Ocean as compared to that of strait of Harmuz (Hussain, Yuan, \& Ali, 2016). 


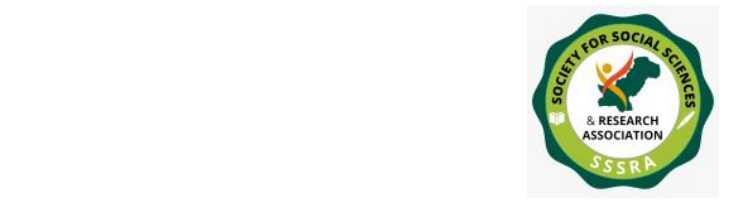

Pak. Journal of Int'L Affairs, Vol 4, Issue 4 (2021)

China Pakistan Economic Corridor (CPEC): ...

Through the Gwadar Port, China can watch the Sea Lines of Communications (SLOC) as almost $60 \%$ of Chinese energy supplies originate from Persian Gulf and move along this passage. In the meanwhile, China can monitor the United States maritime activities in the region (Khan, 2017). In the current scenario of economic race CPEC seems to be a blessing for China.

\section{Opportunities for Pakistan}

The benefits of CPEC for Pakistan are far wide. There is a complete consensus in the Pakistan society for the fruitful results of the CPEC project. The project of the worth US $\$ 46$ billion offers Pakistan to address the main hindrance in the way of economic growth such as energy, infrastructure, transportation and communication, poor condition of railway and a narrow investment from abroad (Hussain, 2017). Pakistani society is mostly agrarian, agriculture contributes 18.5 percent to country's Gross Domestic Product (GDP). Agriculture is a major source in providing employment to Pakistani nation, it employs 38.5 percent people to national labour force and is a total 70 percent of the export. CPEC will prove blessing for the agriculture sector as Chinese enterprises under CPEC, will install number of factories to produce new variety hybrid seeds matching with the climate conditions of Pakistan. Besides this, these factories will develop high quality fertilizers, pesticides and vaccines for the crops to increase crop yield (Hussain, 2020).

Under this project, China will set - up food processing plants to make juices, jams and other number of industrial products from raw fruits like mangoes, oranges and guavas. Such sort of activities will generate employments for locale people of Pakistan, not only this, it will also increase the export of Pakistan to a prominent figure and will add value to the existing raw agricultural products.

Another agreement under the CPEC project is this that China will develop cold storage facilities and logistics in order to save vegetables from being spoiled. At present, almost 50 percent of food including vegetables and fruits is wasted due to transportation.

Pakistan is fourth largest milk producer in the world. China will bring with them new ways of science and technology for livestock breeding. Such scientific how - know will further increase the contribution of livestock in our GDP and will improve the economic conditions of the people living in village areas.

Under the project of CPEC, China will update the irrigation system of Pakistan and will introduce the drip irrigation system to conserve the wastage of water and with this more land will be brought under cultivation. 


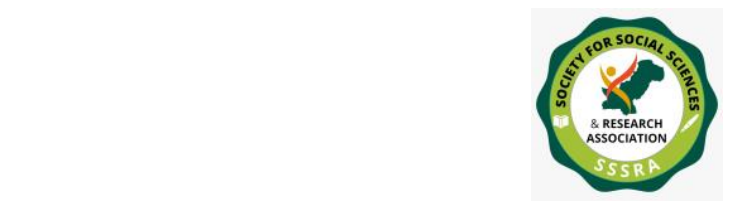

Pak. Journal of Int'L Affairs, Vol 4, Issue 4 (2021)

China Pakistan Economic Corridor (CPEC): ...

Pakistan will undergo a significant journey towards industrialization because of CPEC. According to CPEC plan, the industries to be set up by China will divided into three categories based on their location namely Western, Southern and Central. As Western route consists of Baluchistan and KPK and these regions are rich in mineral resources like chrome, gold, granite, marble and copper. The extraction of these mineral resources can change the fate of the Balochistan and KPK regions (Hussain, 2020).

Southern route is consisting of Karachi and Gwadar, China has intended to install steel, chemical, automobiles and machine industries in these areas while the Central route consists of Punjab and Sindh, rich in agricultural raw material, textile industry will be set up by China in these areas. Overall, industrial set up in the country will bring an economic boost in Pakistan (Hussain, 2020).

Pakistan was facing a serious energy crises before 2013. With the CPEC agreement a handsome amount in the early phase of the project was spent to produce more energy. It is estimated that by 2025, load shedding will be completely eliminated from the Pakistan, hence more than US $\$ 35$ billion has been allocated to energy generation projects with aim to revive local industry (Hassn, 2017).

CPEC is categorized as one of the major project to reduce poverty in Pakistan. CPEC a mega project is expected to produce millions of job in various sectors (Khan \& Khan, 2019).. According to estimation 2.3 million jobs are to be created by 2030. Under CPEC, China will lay down the network of fibre optic cables in Pakistan for the purpose of fast internet and cultural integration between two countries. Moreover, Sea belt from Keti Bandar, Sindh to Iranian border will be developed by constructing spring hotels, apas and public recreation parks (Hussain, 2020). Such sort of activities will promote tourism and recreation in Pakistan.

CPEC project will also create opportunities for the other regional countries for example Central Asian countries and Afghanistan can take advantage of the CPEC project. As the Central Asian countries consisting of Kazakhstan, Uzbekistan, Krygistan, Azerbijan, Tajikistan and Turkmanistan are natural resources rich countries and want to sell their surplus resources but lacking sea waters (Shabbir, 2017). CAR's and Afghanistan would like to become the part and parcel of the CPEC to be shipped towards other destinations (Hussain, 2020).

CPEC is a minor part of wider Belt and Road Initiative (BRI) of China. The main vision of BRI is to connect Asia, Europe and Africa with the network of roads and sea routes. The aim behind this vision could not be reached without regional peace. Obviously, China will 


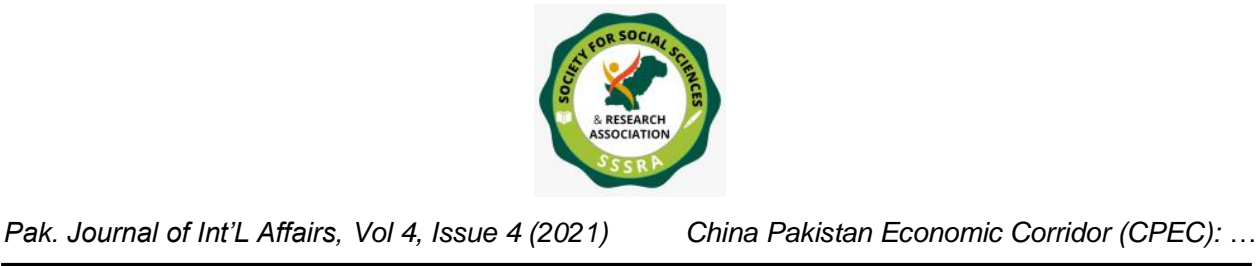

make all its efforts to bring the peace in the region. China's efforts to bring peace in the region can be seen in two ways:

First, China will arrange political settlement of the issues in the regional countries like Afghanistan. Second, China would launch a huge investment in the under developing countries in order to improve the lifestyle of the indigenous people. Such sort of tactics would ultimately bring peace in the region for instance once the people are engaged in the trade activities, they will avoid taking any measure that could harm their economic activities. Thus, CPEC will become a source of peace in the region including Pakistan (Hussain, 2020).

\section{Threats}

The CPEC being a game changer project will not only enhance relations between Pakistan and China but also open new ways of development for both the countries. However, there are certain threats to the mega project of CPEC due to various factors. Mainly There are two type of threats to CPEC, internal threats and external threats. In the following paragraphs the detailed discussion about these threats will be given:

\section{Internal Threats}

The poor governance of Pakistan is a major threat in the way of CPEC. The majority of the politicians is immature, illiterate and less trained that's why the control of government on the various institutions is very weak for instance to pass any project from various governmental departments is very time consuming in Pakistan e.g. obtaining building permit, getting goods passed from customs, paying taxes to Federal Board of Revenue (FBR), getting electricity or gas connection and so on, is very complicated and cannot be done without paying extra money to the concerned authorities. Furthermore, Chinese authorities are not happy with the working colonial governance structure in Pakistan. Without good governance, CPEC will never prove to be a game changer project for Pakistan.

A number of local Baloch people fear that they will be turned into minority in their own province after the influx of workers from other areas. Their intimidation is explained with the example that they turned into minority in Quetta (the capital of the Baluchistan) after the influx of Pathans during Soviet invasion of Afghanistan in 1979. Besides, they have reservations that their natural resources will be exploited by China without providing them their adequate share (Ali, 2016). Thus Baluchistan the key player of CPEC because of its 


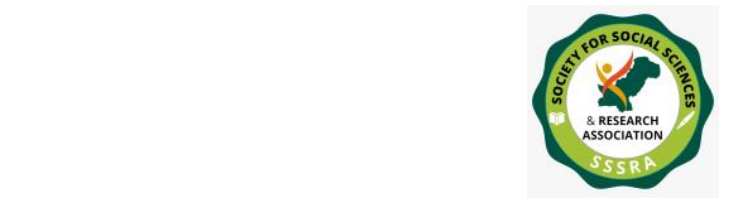

Pak. Journal of Int'L Affairs, Vol 4, Issue 4 (2021)

China Pakistan Economic Corridor (CPEC): ...

Gwadar Port, will continue to act as a threat, unless the concerns of the local people are addressed properly taking Baluch community into confidence.

Another threat to CPEC is from KPK, as the people of KPK are unhappy with the changing route of the CPEC by the federal government. The people of KPK have shown their desire that the western route should be completed first which passes from KPK to Baluchistan and then it connects Gwadar with China. The federal government led by Mian Muhammad Nawaz Sharif changed the route of CPEC which was strongly opposed by the people of KPK. The people of KPK believe that the project of CPEC is more beneficial to Punjab only (Ali, 2016). It is mandatory to solve the reservations of the people of the KPK in order to make the project a successful story.

Pakistan is also facing security issues from various indigenous militant groups and external elements like TTP. Though the military operations against these groups have reduced the threats, but not eliminated completely. Similarly, Chinese engineers have been made the victim of these terrorists (Hussain, Yuan, \& Ali, 2016). In order to encounter security threats to CPEC, the federal government of Pakistan has made a special security division for CPEC. Pakistan, annually spends an enormous amount of Rs 136 billion on its security. This special security division has recruited 9000 army personnel while 6000 civilian armed men. China is still unhappy with Pakistan's measures to encounter the danger from terrorists. Pakistan will have to make its security fool proof in order to make the project a successful game.

\section{External Threats}

India is the only country in South Asia which has rejected the CPEC project arguing that it passes through the controversial territory of Kashmir (Hussain, 2017). India has openly said that it would take measures to make the project a failure one. There are many evidences of Indian army found involved in supporting the militants of Baluchistan Liberation Army (BLA) to create agitation in the province by giving them training in the bases established by India on Pak-Afghan border. Besides, Indian RAW agents are actively engaged in Baluchistan as evident the arrest of Kulbhushan Jadhav. Thus, such sort of Indian activities in Baluchistan are a great threat to the CPEC project (Esteban, 2016).

Another external threat to the CPEC is the functioning of Chabahar Port because it is the only port in the region which gives an alternative way to the Central Asian Republics, China and Afghanistan to reach Arabian Sea via Iran. India has already invested billions of dollars in Tehran to make Chabahar Port successful. On the other side, Iran is a peaceful country with better government structure as compared to that of Pakistan and is also one of 


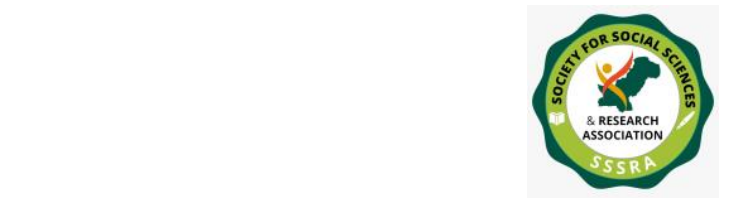

Pak. Journal of Int'L Affairs, Vol 4, Issue 4 (2021)

China Pakistan Economic Corridor (CPEC): ...

the largest oil producing country in the world. These virtues of Iran are sufficient to attract the regional countries to use Iranian corridor instead of Pakistan. Therefore, Iran is a good competitor of Pakistan for its route transit and Chahbahar port which could be serious threat to CPEC (Nazir, 2016).

Hybrid warfare is another threat to the successful story of CPEC. It involves such kind of fake news and propaganda that it turns the local people against any project. One of the major threats to the CPEC is the hybrid warfare. For example, the fake news were circulated in the various platform of the media that the project of CPEC will prove another "East India Company." (Hussain, 2020). Many experts across the world believe that the project of CPEC will ultimately push Pakistan into dept trap. These kind of remarks are totally baseless, fake and not more than a propaganda against the interests of Pak-China relations. But unfortunately, the mega project of CPEC is facing such kind of propaganda to a larger extent.

\section{Conclusion}

The project of CPEC has substantial importance for both China and Pakistan as it is a source to provide China a shortest possible route to connect it with Central Asian States, countries in West and South Asia and further to Europe. Moreover, this project will play a key role to reduce distance for oil transportation from the Gulf countries to China. Additionally, this project will enable China to become a major import-export catalyst in the world. Besides this it will enhance the trade between China and Pakistan.

It is going to be anticipated that the project of CPEC will benefit billions of people in the regional as well as in the international circles for its intra-regional connectivity. Therefore, as a flagship project of BRI, the project of Pakistan China Economic Corridor is very fundamental for its success. This mega project is an extra ordinary example of China's friendly relations towards Pakistan, offering Pakistan the same towards China by broadening and strengthening peaceful economic and strategic relations.

It is important to highlight that the War on Terrorism since 2001 and the worst security situation in the region has badly affected Pakistan's economy. In such situation this pilot project is a blessing for Pakistan for its multi-dimensional benefits. Besides, increasing the trade between two countries it will also generate huge commercial and economic openings that will ultimately help to create jobs.

Since the last two decades, Pakistan is suffering from energy crises and hence, facing worst economic activities. Under CPEC several energy and infrastructure projects will ultimately 


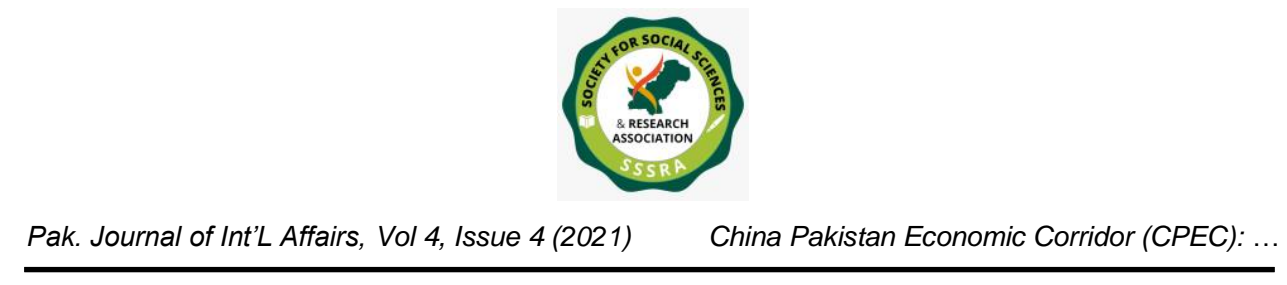

create healthy economic activities in Pakistan. This mega project will help Pakistan to overcome energy crises by increasing its capacity to produce more energy for Pakistan to accomplish Pakistan's energy needs. Besides this, Pakistan plans to establish Special Economic Zones throughout the country as a vital feature of this mega project. The construction of SEZs in various areas of Pakistan will increase economic activities in Pakistan and hence, will become a source to produce more goods to earn foreign exchange.

The development of the port and airport at Gwadar and the construction of eastern, western and central route will tie all the province and regions within the country. This will enable the Pakistan's farmer to have a direct access to the local markets to sale their produce (goods) at reasonable prices. Furthermore, the huge investment from China will come into Pakistan that will be a healthy indicator for rest of the world to invest in Pakistan because a joint security plan is being made with the help of China in order to encounter all possible terrorist threats.

In order to avail all possible opportunities of CPEC project, a complete consensus from all the political groups and other active groups is needed because such sort of acts will give a soft image of Pakistan to the international circles. A strong security plan is needed to eradicate the terrorist activities in Pakistan. A fool proof law and order situation in Pakistan can win the trust of the international community to have a safe and secure investment in Pakistan. Pakistan government, security agencies and policy-makers will have to work head to head to provide a fool proof security system to the foreign investors.

The project of China Pakistan Economic Corridor (CPEC) encounters both opportunities and threats. Threats of CPEC range from Indian opposition, development of Chabahar Port as an alternative to the CPEC, internal and external security threats, and reservations of people of Baluchistan and KPK are the major threats to the project of CPEC. while the opportunities of the CPEC project are far wide as compared to that of threats. The range of opportunities consists of flourishing of agriculture sector, increase in the industrialization process, overcoming of energy crisis, creating of new employment for the people of Pakistan, installation of optical fiber, enhancing of the tourism and bringing stability and peace in the region are the few of the vital opportunities of the project CPEC. From the analysis of the study it is concluded that the CPEC can be a game changer plan for Pakistan if it is implemented properly and timely eliminating all threats to the project. Pakistan will have to make a master plan in order to encounter all kinds of threats because Pakistan's peace and prosperity is very conditional to the successful story of the CPEC. The successful CPEC is a guarantee to further development in the bilateral relations between Pakistan and China in terms of politics, strategic and economic activities. Pakistan 
will have to pave the way for the smooth progress of the CPEC project because of the bright future of the Pakistan is associated with successful CPEC. 


\section{References}

Abid, M., \& Ashfaq, A. (2015). CPEC: Challenges and opportunities for Pakistan. Journal of Pakistan Vision, 16(2), 142-169(150).

Ali, A. (2016) China Pakistan Economic Corridor: Prospects and Challenges for Regional Integration. Arts and Social Sciences journal, 1-5(1).

Ali, M. (2018). The China-Pakistan Economic Corridor: Tapping Potential to Achieve the 2030 Agenda in Pakistan. China Quarterly of International Strategic Studies. 4. https://www.researchgate.

Energy. (2019). China Pakistan Economic Corridor. https://cpecinfo.com.

Esteban, M. (2016). The China-Pakistan Corridor. Strategic Studies, 36(2), 63-74.

Hassn, k. (2017). A Pakistani Overview of Pakistan-China Relations: From Geopolitical Compulsions to a Strengthening Co-operation. Asia centre. 1-12 (5).

Hussain, J., Yuan, Z., \& Ali, G. (2016). China Pakistan economic corridor. Defence Journal, 19(6), 19.

Hussain, M. (2017). China Pakistan Economic Corridor (CPEC): Challenges and the way $\begin{array}{llll}\text { forward. Naval } & \text { Postgraduate }\end{array}$ https://apps.dtic.mil/sti/citations/AD1046419

Hussain, S. (2020). Challenges and Opportunities of CPEC. (Web). https://theauthenticpost.com/challenges-and-opportunities-of-cpec/

Irshad, M. S. (2015). One belt and one road: dose China-Pakistan economic corridor benefit for Pakistan's economy?. Journal of Economics and Sustainable Development, 6(24), 202.

Khan, H. U. (2017). China Pakistan Economic Corridor (CPEC): Benefits for Pakistan. .p.45. http://hdl.handle.net/10945/56582

Khan, M. Z. U., \& Khan, M. M. (2019). China-Pakistan Economic Corridor. Strategic Studies, 39(2), 67-82 (70). 
Khan, N., Ahmad, R., \& Xing, K. (2018). China Pakistan Economic Corridor (CPEC): Regional Development, Employment Opportunities and Policy Challenges. Global Political Review, 3(1), 12-23 (16).

Markey, D. S., \& West, J. (2016). Behind China's gambit in Pakistan. Council on Foreign Relations, 5(1), 5.

McCartney, M. (2018). The China-Pakistan economic corridor (CPEC): Considering contemporary Pakistan through old-fashioned economics and historical case studies. The Lahore Journal of Economics, 23(2), 19-48 (23).

Ministry of Planning, Development and Reforms (2021). Government of Pakistan. https://www.pc.gov.pk/

Nazir, M. (2016). Macro and Micro Dividends of CPEC. Islamabad Policy Research Institute, November, 1.

Shabbir, T. (2017). Pakistan-China Relations in the Post-Cold War Period: Regional and Global Implications.(Doctoral dissertation)., 142. Quaid-i-Azam University Islamabad.

Siddique, H. A. (2015). CPEC Projects: Status, Cost and Benefits. https://www.dawn.com/news/1194014. 